\title{
Listening to Young Children: Toward Agency, Equity, and Deeper Learning
}

\author{
Martha M. Foote, EdD \\ Professor \\ Department of Curriculum and Instruction \\ Texas A\&M University-Commerce \\ Commerce, TX 75402 \\ United States
}

\begin{abstract}
In previous centuries childhood was considered to be at a lower hierarchy in terms of valuing human life and education. Today, the early years are recognized as critical in terms of a child's learning and learning how to learn. With the goal of deep learning in mind, a recognition that an authentic and deep level of listening to young children by teachers and adults is a readily available strategy and opportunity for schools to support children's early years of education. This paper provides a case for why listening can be so valuable and how teachers and adults can be more thoughtful and reciprocal with this process. With ongoing opportunities to be taken seriously as they interact and express their thoughts, young children can be afforded experiences to better develop their agencies to think, create, express, connect, and be the kind of deep learner needed to thrive in the world.
\end{abstract}

Key words: Early Childhood Education, Listening, Deep Learning, Agency, Equity

\section{Historical Background of Valuing Childhood}

A keynote session at the 2019 annual conference of the National Association for the Education of Young Children is described as focusing on "Overcoming the Belief in a Hierarchy of Human Value: What Early Childhood Educators and Parents Can do" (Christopher, 2019). This topic runs counter to the notion that the period of childhood is of lesser importance in terms of education or the respect and seriousness with which adults respond to children. Yet, the history of mankind reveals that children have not always occupied a position of worth or concern in the eyes of adults. In contrast to the ability of most two- or three-year-olds of today to indicate their age by a show of fingers, children of the sixteenth century rarely even knew how old they were (Aries, 1965). This was not considered a matter of importance since childhood itself was believed unimportant.Medieval art contained no children, but by the fifteenth century children began to appear in crowds, portrayed simply as miniature adults with no awareness of the particular feature of children (Aries, 1965), In the eighteenth and nineteenth centuries, the idea of educating children gained credence. However, it took the form of strict discipline with severe tactics for enforcement. These schools tended to focus on quieting children and suppressing the spirit of childhood (Aries, 1965).

Beginning in the twentieth century the need for early childhood education has been realized and has taken more appropriate forms. The period of early childhood is now recognized as crucial in the total development of a person (White, 1985; Bruner, 2002; Edwards, Gandini, and Forman, 2012). Early childhood teachers, parents, and others in a child's life now consider serious listening to the ideas, thoughts, theories, and questions of children a potentially vital kind of response. However, mere recognition that children need to be heard does not insure a change in the substance or nature of "the listening response" of adults. Once the impact of a deeper kind of listening are understood, teachers, parents, and others can make use of this insight in valuing children's thinking and "meaning-making" in order to better support the development of both.

\section{Listening to Children Promotes Confidence in their Ideas}

Just as self-confidence and trust in one's ability to learn new skills provides tremendous impetus toward the actual accomplishment of the skills, an adult's attentive listening as children articulate their plans or hypothesize about the way something works can likewise support a child's confidence and willingness to express their ideas, speculations, and theories as they attempt to make sense of the world. CarlinaRinaldi (2006) explains more about how children develop theories in her description of the genesis of "the pedagogy of relationships and listening" which has evolved in the preprimary schools of Reggio Emilia, Italy:

For adults and children alike, understanding means being able to develop an interpretive 'theory', a narration that gives meaning 
to events and objects of the world. Our theories are provisional, offering a satisfactory explanation that can be continuously reworked; but they represent something more than simply an idea or a group of ideas. They must please us and convince us, be useful, and satisfy our intellectual, affective and aesthetic needs (the aesthetics of knowledge).

In representing the world, our theories represent us (Rinaldi, 2006, p. 64)

Rinaldi contends that one's theories need to be listened to by others. She further points out that "sharing theories is a response to uncertainty" (Rinaldi, 2006, p. 64).

\section{Articulating to Clarify Thinking}

Additionally, a child's own understanding is often made more clear even to herself as she describes her plans to create something new. An adult who takes the child's plans seriously can send the message that the approach is reasonable; and, can simultaneously scaffold the process by asking critical questions that could help the child identify additional aspects needed for the plan's success. (Vygotsky, 1978; Bokrove and Leong, 1996). Listening as an active process, involves giving one's total attention to the words and context, and includes ongoing interpretation. When this is done, the teacher is in a position to participate in a reciprocal relationship with the child; thereby valuing the child's thoughts and the child as well. The child's confidence in their abilities to think and to communicate can be strengthened through this experience of reciprocity between the adult and the child.

\section{Listening to Children Promotes Their Sense of Agency}

According to pioneering child development theorist James Hymes (1949), when adults are responsive to what a child has to say, it provides a sense of independence,or agency, and lays the foundation for further independent action. Children of all ages need agency and have purposes to fulfill. Additionally, if these purposes become unattainable, they may become an overriding concern later in life (Hymes). When listening to a child in order to understand what they know or want to express, teachers can gain insight into not only their current level of understanding of a particular concept but also the vital needs or misconceptions the child may have at the time. The adult is then in a position to know how best to provide feedback, teach a needed skill, or designan instructional provocation to lead the child's learning to the next level.

A listening adult also serves as a model for how to listen. By observing an adult in the concentrated act of listening, a child can begin to understand that listening is a worthwhile and essential activity. Listening, however, is not easy.

Rinaldi states that it requires " a suspension of our judgments and above all our prejudices; it requires openness to change" (Rinaldi, 2006, p. 65). This deeper kind of listening takes away the anonymity of the speaker in relation to their ideas. The listener must value the unknown in order to be open enough for the speaker's message to become evident. The process can enrich both the speaker and the listener due to the respect being afforded for what can be discovered together.

\section{So, What Is Involved in "Deeper Listening”?}

So, what does the deeper kind of listening look like in day-to-day interactions between teachers and children? Louise Cadwell (1997) has offered several suggestions for supporting conversations with childrenin turn will also provide the opportunity for deep listening, a few of which are described below. First, she recommends brainstorming, perhaps with colleagues, questions that challenge children to "wonder and hypothesize, invent and compare" (Cadwell, 1997, p.70). Cadwell also recommends careful consideration and planning for the composition of groups. "For example, the combination of interested children with less interested children, verbal with not so verbal, can work....A group of five seems to be an ideal small number group." Cadwell emphasizes to let children know that you are not there to quiz them; that instead your goal is "to wonder and search with them and that you are interested in big ideas and you know they are, too" (Cadwell, 1997, p.70). Two final points for supporting meaningful conversations is to assure the children with your tone of voice and your words that you are excited to participate in the conversation and believe in their capacities for having worthwhile ideas, creative hypotheses, and to think critically about theories proposed.

Transcribing conversations with children can also be a powerful tool which affords the opportunity for listening deeply. When children see that their words and contributions to a discussion have been recorded, it sends the message that what they say is valued. If the transcription is placed on display, for instance on a chart, or read back to them in a subsequent session, it can help them reflect on what's been said and then move forward with additional ideas, plans, or questions. Cadwell (1997, p. 70) also emphatically stresses that teachers should "enjoy the conversation! Laugh together. Be amazed at their perspectives. Share some of yours." 
Oral language development as well as enhancement of social connections are also key areas that benefit from this reciprocal process of back and forth conversation between an early childhood professional and the child; parent and child; or even two children conversing, listening, and responding to each other's ideas. Listening and speaking skills are a necessary foundation for literacy and success in school and generally in life (Bruner). By listening and responding when children speak, teachers and parents become stimulators of languageand "the social construction of knowledge" (Vygotsky, 1978). Still, it must be recognized that teachers and children will need time and many opportunities for this kind of interaction. Most children may not have had many experiences with adults who are taking their thoughts this seriously and that truly want to know what they think. Analyzing children's conversations with colleagues can often provide insight into children's level of knowledge and understanding, theories, new questions, and also their ease in conversing with others (Cadwell, 1997).

\section{Can Deeper Listening Lead to Deep Learning}

Jal Mehta and Sarah Fine (2019) conducted a study to search for "deeper learning" and found that the most consequential learning occurred when students had opportunities to master knowledge and skills, saw themselves as connected to what they are learning; and, had opportunities to produce or contribute something new. While this study was conducted with older students, it is compelling to consider the kinds of similar opportunities young children would have when engaging in thoughtful and serious conversation with adults who listen with the intent to respond seriously and then lead their learning.

Fullan, Gardner, and Drummy(2019) have called for "deep learning" as the moral imperative of our times. In light of the broader landscape in today's world, Fullan and colleagues point toward the increasing number of students showing lower and lower well-being scores due to an array of societal factors. Trends such as the increasing gap between rich and poorer, climate change, and the effects of technology, which can create superficial connections, are all contributing to the pervasive stress and anxiety reported by today's students. Confirming this conclusion, there has been a steady decline in students' sense of belonging and connectedness at school from 2003 to 2015 according to PISA data (0ECD, 2017). Fullan and colleagues call for a focus on "deep learning" and define it as follows: "Learning that helps them make connections to the world, to think critically, work collaboratively, empathize with others, and most of all, be ready to confront the huge challenges that the world is leaving their generation" (Fullan, et.al, p. 66). Likewise, educators such as Ron Berger (2003) have championed giving students the time and support to create "beautiful work" often requiring iterations whether the product is an essay, inquiry project, or solution to a math problem. It is the processes required of the work that are valued and lead to a high quality craftsmanship the child can then create.

\section{Conclusion}

Society has come a long way since the fifteenth century when childhood was considered to be at a lower hierarchy in terms of valuing children and their needs. With the goal of deep learning in mind, a thoughtful, reciprocal, and equitable stance of listening to young children seems to be a readily available strategy and opportunity for schools to support children's early years of education. With ongoing opportunities to be taken seriously as they interact and express their thoughts, young children could be afforded experiences to better develop their agencies to think, create and express, connect, and be the kind of deep learner needed to thrive in the world. Research to learn more about the impact of deep listening to young children is a frontier worthy of exploration.

\section{References}

Aires, P. (1965).Centuries of childhood: A social history of family life. New York: Vintage Books.

Berger, Ron. (2003). An Ethic of Excellence: Cultivating a Culture of Craftsmanship in the Classroom. Portsmouth, $\mathrm{NH}$ : Heinemann

Bruner, Jerome S. (2002). Making Stories: Law, Literature. New York: Life. Farra.

Bodrova, E. and Leong, D. J. (1996). Tools of the mind: The Vygotskian approach to early childhood education. Columbus, Ohio: Merrill.

Cadwell, L. (1997). Bringing Reggio Emilia home: An innovative approach to early childhood education. New York: Teachers College Press.

Christopher, G. C. (2019). "Overcoming the Belief in a Hierarchy of Human Value: What Early Childhood Educators and Parents Can Do", Presentation at the NationalAssociation for Education of Young Children Annual Conference.

Edwards, C., Gandini, L., \& Forman, G. (Eds.). (2012). The hundred languages of children: The Reggio Emilia approach - advanced reflection. (3rd Ed.) Santa Barbara, CA: Praeger. 
Fullan, Gardner, and Drummy (May, 2019) “Going Deeper”, Educational Leadership, Association for Supervision, and Curriculum Development, 64-69.

Hymes, J. L. (1949). Teacher listen, the children speak. New York: New YorkCommittee on Mental Hygiene of the Stte charities Aid Association.

Mehta, J. and Fine, S. (2019). In search of deeper learning: The quest to remake the American high school. Cambridge, MA: Harvard University Press.

OECD, (2017). PISA 2015 Results (vol 3). OECD iLibrary.

Rinaldi, C. (2006). In dialogue with Reggio Emilia: Listening, researching and learning, New York: Routledge.

Vygotsky, L. (1978). Mind in society: The development of higher psychological processes. Cole, M., John-Steiner, V., Scribner, S., and Souberman, E. (Eds.) Cambridge, MA: Harvard University Press.

White, B. L. (1985). The First Three Years of Life. New York: Prentice-Hall. 